\title{
Kalendarze pomorskie* ze zbiorów Biblioteki Uniwersyteckiej w Toruniu
}

\section{Wprowadzenie}

$\mathrm{K}^{\mathrm{a}}$ alendarze towarzyszą człowiekowi od wieków. Na przestrzeni lat zmieniał się jedynie ich charakter. Początkowo wskazywały one dni, tygodnie, miesiące, wschody i zachody Słońca oraz fazy Księżyca. Można było w nich odnaleźć wykazy świąt kościelnych, imion świętych, przepowiednie. W wieku XIX na ich łamach - oprócz kalendariów - zaczęły pojawiać się teksty literackie, a także artykuły dotyczące regionu, w którym kalendarz był wydany, wiadomości społeczno-polityczne, religijne, wykazy jarmarków, porady rolnicze oraz dowcipy i opowiastki satyryczne. Znaczną część każdego kalendarza zajmowały też reklamy firm działających na danym terenie. Podobny charakter miały kalendarze w pierwszej połowie XX w. Jak podaje Ewa Wójcik ${ }^{1}$, wydawcą większości kalendarzy w tym okresie był Kościół katolicki i związane z nim organizacje świeckie. Poza tym ich publikacją zajmowały się stowarzyszenia i związki zawodowe, organizacje społeczne, młodzieżowe i studenckie, firmy prywatne, towarzystwa dobroczynne i charytatywne. Wiele kalendarzy ukazywało się

* Terminem kalendarze pomorskie $\mathrm{w}$ artykule określono kalendarze wydane na terenie województwa pomorskiego (1920-1939) oraz w Wolnym Mieście Gdańsku, a także na ziemiach na zachód od granic dawnego województwa pomorskiego (należących wówczas do Niemiec). Współcześnie są to tereny obecnych województw: pomorskiego, kujawsko-pomorskiego i zachodniopomorskiego.

${ }^{1}$ E. Wójcik, Kalendarze dwudziestolecia międzywojennego: dzieje, problemy literatury i kultury, bibliografia, Kraków 2000, s. 41-64. 
również nakładem firm wydawniczych i księgarskich, a także jako efekt działalności redakcji gazet i czasopism.

Jeszcze do niedawna kalendarze nie cieszyły się szczególną uwagą badaczy. Obecnie, dzięki treściom w nich zawartym, coraz częściej są traktowane jako doskonałe źródło wiedzy o regionie, życiu społeczno-politycznym i religijnym czy wreszcie źródło do badań na temat zainteresowań czytelniczych.

\section{Projekt digitalizacii kalendarzy Biblioteki Uniwersyteckiej w Toruniu}

2008 r. w Bibliotece Uniwersyteckiej w Toruniu (dalej: BU) w ra-
mach grantów bibliotecznych powstał projekt zatytułowany „Kalendarze pomorskie z XIX i pierwszej połowy XX wieku ze zbiorów Biblioteki Uniwersyteckiej w Toruniu - digitalizacja i udostępnienie on-line w Kujawsko-Pomorskiej Bibliotece Cyfrowej (dalej: KPBC)". Celem projektu była konwersja cyfrowa kalendarzy wydanych w tym okresie na Pomorzu oraz ich rozpowszechnienie w ramach regionalnej biblioteki cyfrowej. Jego realizację poprzedziło zredagowanie planu działania, który przewidywał:

- sporządzenie wykazu kalendarzy pomorskich znajdujących się w zbiorach BU,

- przygotowanie spisu kalendarzy pomorskich pochodzących ze zbiorów Książnicy Kopernikańskiej w Toruniu i ewentualne zlokalizowanie ich $\mathrm{w}$ innych bibliotekach regionu (odszukanie roczników uzupełniających zbiory BU),

- opracowanie formalne i rzeczowe wydawnictw w systemach Horizon i dLibra,

- przygotowanie kalendarzy do digitalizacji,

- skanowanie wydawnictw oryginalnych i przetwarzanie materiału cyfrowego,

- udostępnienie zasobów w KPBC i archiwizacja kopii cyfrowych na płytach DVD.

Odszukanie kalendarzy w zbiorach BU nie było zadaniem trudnym, ponieważ opisy kalendarzy wydanych po 1800 r. są umieszczone w katalogu kartkowym czasopism pod wspólnym hasłem „kalendarz” (w jego 
ramach tytuły szereguje się alfabetycznie). Opisy nielicznych kalendarzy zarejestrowano także w katalogu komputerowym Horizon. Poszukiwania roczników brakujących w zbiorach BU, a zlokalizowanych w Książnicy Kopernikańskiej, umożliwił zeskanowany katalog czasopism tej biblioteki. Niewystępujące w zbiorach BU roczniki kalendarzy grudziądzkich odnaleziono z kolei w Bibliotece Miejskiej im. Wiktora Kulerskiego w Grudziądzu. Poszukiwania ułatwiła również Bibliografia czasopism pomorskich zredagowana przez Henryka Baranowskiego ${ }^{2}$, a także wspomniana wcześniej publikacja Ewy Wójcik, której część drugą stanowi bibliografia kalendarzy dwudziestolecia międzywojennego ${ }^{3}$.

Po zapoznaniu się z zawartością katalogu BU wyłoniono 8 opisów kalendarzy pomorskich wydanych $\mathrm{w}$ XIX $\mathrm{w}^{4}{ }^{4}$ i 63 opisy kalendarzy wydanych w pierwszej połowie XX w. ${ }^{5}$ Ponieważ po wstępnych oględzinach stwierdzono, że przed procesem digitalizacji kalendarze XIX-wieczne będą wymagać jeszcze pewnych prac konserwatorskich, digitalizację tych wydawnictw przesunięto w czasie, a proces skanowania (mimo że chronologia wskazywałaby inaczej) rozpoczęto od kalendarzy, które ukazały się $\mathrm{w}$ pierwszej połowie XX $\mathrm{w}$.

Z tej grupy do digitalizacji wybrano 16 kalendarzy opublikowanych w języku polskim na terenie południowych powiatów dawnego województwa pomorskiego, tj. w powiecie świeckim, grudziądzkim, nowomiejskim, chełmińskim, brodnickim, wąbrzeskim i toruńskim. Stan kalendarzy przechowywanych w zbiorach $\mathrm{BU}$, mimo że były to wydawnictwa często zaczytane, z założenia przeznaczone przecież do użytku przez jeden rok, był zadowalający. Jedynie w kilku przypadkach konieczne okazało się przeprowadzenie drobnych zabiegów konserwatorskich, głów-

${ }^{2}$ Bibliografia czasopism pomorskich: województwo bydgoskie, pod red. H. Baranowskiego, Toruń 1960.

${ }^{3}$ E. Wójcik, dz. cyt.

${ }^{4}$ Wśród kalendarzy XIX-wiecznych znajdujących się w zbiorach BU 3 zostały wydane w języku niemieckim w Gdańsku, Szczecinie i Dębnie, 5 - w języku polskim w Toruniu (3) i w Chełmnie (2).

${ }^{5}$ Kalendarze wydane w pierwszej połowie XX w. są reprezentowane w zbiorach BU przez 40 tytułów wydanych w języku polskim oraz 23 tytuły wydane w języku niemieckim. W pierwszej grupie znajdują się wydawnictwa opublikowane w Bydgoszczy (10), Toruniu (6), Grudziądzu (4), Włocławku (4), Gdyni, Kartuzach i Nowym Mieście Lubawskim (w każdym mieście po 2) oraz Brodnicy, Chełmży, Gdańsku, Górnej Grupie, Inowrocławiu, Szczecinie, Tczewie, Pelplinie, Wąbrzeźnie i Wejherowie (po 1). Grupę drugą tworzą kalendarze wydane w Gdańsku (6), Szczecinie (5), Dębnie (3) oraz Człuchowie, Kołobrzegu, Lęborku, Pile, Słupsku, Świeciu, Świnoujściu, Szczecinku i Sztumie (po 1). 
nie renowacji uszkodzonych okładek i stron tytułowych. Wśród almanachów zakwalifikowanych do digitalizacji znalazły się kalendarze wydawane przez redakcje gazet, kalendarze katolickie oraz jeden kalendarz rolniczy.

\section{Kalendarze toruńskie}

$\mathrm{N}^{2}$ ajwiększa liczba kalendarzy zdigitalizowanych w ramach opisywanego projektu i opublikowanych na łamach KPBC, czyli 6 tytułów, to kalendarze wydane w Toruniu (w okresie międzywojennym ukazywało się tu aż 14 tytułów).

Wśród nich na szczególną uwagę zasługuje „Ilustrowany Kalendarz Słowa Pomorskiego", wydawany w latach 1928-1939 drukiem i nakładem Drukarni Toruńskiej. Ukazywał się on jako bezpłatny dodatek do „Słowa Pomorskiego". Pierwszy rocznik nosił tytuł „Kalendarz Pomorski”, dalsze wydawane były pod tytułem „Ilustrowany Kalendarz Słowa Pomorskiego", a kolejne miały często odmienne tytuły okładkowe: „Bezpłatny Kalendarz Słowa Pomorskiego”, „Kalendarz Słowa Pomorskiego” czy też „Słowo Pomorskie: kalendarz ilustrowany”. Choć tematyka kalendarza była różnorodna, to przeważały tu artykuły dotyczące Torunia i Pomorza, zgodnie z założeniem redakcji, która we wstępie do pierwszego rocznika pisała: „przeto na pierwszym miejscu uwzględniliśmy Pomorze, czy to w informacjach, czy w popularnych artykułach" ${ }^{\prime 6}$. W kalendarzu publikowano liczne artykuły związane $\mathrm{z}$ historią i sztuką Torunia, wiadomości o działających na Pomorzu związkach i towarzystwach, a także wiele informacji dotyczących życia społeczno-politycznego zarówno w II Rzeczypospolitej, jak i na świecie. Sporo miejsca zajmowała też tematyka kościelna, zwłaszcza wykazy władz i organizacji kościelnych. W każdym roczniku zamieszczano ponadto aktualne informacje o jarmarkach, targach odbywających się w województwie pomorskim i wielkopolskim, a także w Wolnym Mieście Gdańsku. Nie brakowało również porad gospodarczych, prognoz pogody, dowcipów oraz reklam firm działających w Toruniu i regionie. Poruszając tematykę dotyczącą kalendarzy, nie sposób nie zwrócić uwagi na artykuł zamieszczony w roczniku 1928 omawiane-

${ }^{6}$ Do naszych Czytelników, „Kalendarz Pomorski na rok 1928”, s. 2. 
go tytułu, a poświęcony dawnym kalendarzom toruńskim wydawanym w XVIII i XIX w. ${ }^{7}$

Kolejny toruński kalendarz w zbiorach BU to „Kalendarz Ludowy” bezpłatny dodatek do "Głosu Robotnika” i „Obrony Ludu” - ukazujący się w latach 1928-1939 nakładem Drukarni Robotniczej W. Pawlak i Spółka w Toruniu. Miał on skromną szatę graficzną. Na jego łamach publikowano artykuły tematycznie dotyczące Torunia i regionu, związane np. z 700-leciem miasta, 10. rocznicą powrotu Pomorza do Polski czy też jubileuszem 10-lecia Drukarni Robotniczej. Ponadto zamieszczano tu popularne wiadomości o Polsce i świecie, praktyczne porady dla rolników i gospodarstw domowych oraz przepisy prawne przeznaczone dla robotników.

Następne warte omówienia wydawnictwa to dwa kalendarze katolickie: „Kalendarz Królowej Różańca Świętego” - ukazujący się w latach 1937-1939 - oraz „Kalendarz Katolicki Wielkiego Pomorza na rok 1939”. Obydwa tytuły były publikowane z inicjatywy Instytutu Różańcowego w Toruniu (w latach 1930-1936 Instytut Wydawnictw Różańcowych w Karnkowie), który za cel stawiał sobie propagowanie mariańskiej idei różańcowej na łamach wydawanych przez siebie publikacji ${ }^{8}$. Oprócz kalendarium, tabeli świąt i spisu świętych, na kartach obydwóch kalendarzy zamieszczono informacje na temat hierarchii kościelnej, liczne artykuły dotyczące Kościoła katolickiego na ziemiach polskich, opisy miejsc pielgrzymkowych, a także informacje o stowarzyszeniach katolickich. Publikowano tu też utwory poetyckie i opowiadania. „Kalendarz Królowej Różańca Świętego” był wydawany również na życzenie, tj. w mutacjach dla różnych parafii. Zawierał wówczas od 4 do 12 stron poświęconych wiadomościom z życia parafii, dla której był przeznaczony. W zbiorach BU znajduje się taki kalendarz wydany dla parafii Prokocim, natomiast bibliografia kalendarzy dwudziestolecia międzywojennego ${ }^{9}$ notuje jeszcze mutacje dla parafii dąbrowskiej, fordońskiej, Pruchna i oo. Franciszkanów w Wilnie. „Kalendarz Katolicki Wielkiego Pomorza”, powielający treść „Kalendarza Królowej Różańca Świętego”, był wzbogacony o artykuły krajoznawcze i historyczne poświęcone Toruniowi i Pomorzu. Obydwa kalendarze w 1939 r. były sprzedawane jako cegiełki na budowę kościoła Królowej Różańca Świętego.

7 A. R., Dawne kalendarze toruńskie, „Kalendarz Pomorski na rok 1928”, s. 36-40.

${ }^{8}$ Ku chwale Maryi: reportaż z działalności Instytutu Różańcowego, „Kalendarz Królowej Różańca Świętego na rok 1939", s. 33-35.

9 E. Wójcik, dz. cyt., s. 83-84. 
Zupełnie inny charakter miał „Pomorski Kalendarz Rolniczy” - ukazujący się w latach 1924-1929, 1937, 1939 nakładem i drukiem Pomorskiej Drukarni Rolniczej. Redagowany był przez fachowców, inżynierów rolnictwa - początkowo Józefa Fronia, następnie Jana Lentza (redaktora czasopisma rolniczego „Kłosy”) oraz inż. Tomasza Zana i inż. Władysława Jacynę. Już sam tytuł wskazywał na zawartość kalendarza. Prawie w całości był on poświęcony problematyce rolniczej. Zawierał obszerne artykuły i porady z zakresu hodowli zwierząt i uprawy roli, a także prowadzenia gospodarstwa domowego czy wykazy instytucji związanych z rolnictwem. Ponadto mieściły się w nim również działy literacki i społeczno-polityczny.

\section{Kalendarze grudziądzkie}

Spośród 11 kalendarzy wydawanych w Grudziądzu w pierwszej poSłowie XX w. w zbiorach BU znajdują się 4 tytuły. Dwa pierwsze, tj. „Grudziądzki Kalendarz Maryański”, ukazujący się w latach 1905-1939 nakładem i drukiem „Gazety Grudziądzkiej”, oraz równolegle wydany w 1924 r. w tym samym wydawnictwie "Grudziądzki Kalendarzyk Marjański” - to bezpłatne dodatki do „Gazety Grudziądzkiej”. Pierwszy z nich zawierał fragmenty powieści, opowiadania historyczne, utwory poetyckie, a także porady gospodarskie, kronikę wydarzeń, teksty satyryczne i reklamy. Drugi, który ukazał się jedynie w 1924 r., prawie w całości był poświęcony Polskiemu Stronnictwu Ludowemu oraz ludziom z nim związanym, do których należał również Wiktor Kulerski - wydawca „Gazety Grudziądzkiej".

W latach 1925-1926 dodatkiem do „Gazety Grudziądzkiej” był także „Kalendarz Roku Świętego”.

Kolejnym niezwykle interesującym kalendarzem jest wydany w 1925 r. w tym samym wydawnictwie „Kalendarz Jubileuszowy 30-lecia Gazety Grudziądzkiej”. Zawierał on ciekawe informacje dotyczące Wiktora Kulerskiego i prowadzonego przez niego wydawnictwa, drukarni i księgarni oraz ludzi z nim związanych. Wszystkie grudziądzkie kalendarze wydane w wydawnictwie Wiktora Kulerskiego miały bardzo ciekawą szatę graficzną, kolorowe okładki oraz dołączone reprodukcje malarstwa na kredowym papierze. Były przygotowane z dużą starannością. 
W zbiorach BU warto odnotować wreszcie 7 roczników „Kalendarza Słowa Bożego". Był to tytuł wydawany przez Zakład Misyjny Św. Józefa Zgromadzenia Księży Werbistów, którzy w 1923 r. pojawili się w Górnej Grupie - niewielkiej miejscowości niedaleko Grudziądza. Wydawali oni liczne czasopisma oraz 2 kalendarze. Wspomniany „Kalendarz Słowa Bożego" ukazywał się w latach 1920-1940, 1947-1949 i był drukowany kolejno w Bytomiu, Rybniku, Wąbrzeźnie i Grudziądzu, a od 1931 r. w nowo powstałej drukarni w Górnej Grupie. Redaktorem kalendarza był ojciec Stanisław Kubista ${ }^{10}$, pełniący równocześnie funkcję dyrektora drukarni ${ }^{11}$. Poszczególne roczniki kalendarza zawierały wiele ciekawych artykułów dotyczących misjonarzy Słowa Bożego, historii zgromadzenia werbistów oraz prowadzonej przez nich działalności misyjnej. Wiadomościom z misji towarzyszył ciekawy materiał fotograficzny.

\section{Pozostałe kalendarze pomorskie}

W KPBC został również opublikowany „Kalendarz Kościelny dla Parafji Chełmżyńskiej - Posłaniec Błogosławionej Juty", wydany w 1928 r. przez ks. prałata Józefa Szydzika, nakładem Drukarni Toruńskiej. Zawierał on informacje o księżach, wiadomości parafialne, mowy okolicznościowe wygłoszone z okazji przyjęcia ks. biskupa Stanisława Okoniewskiego oraz artykuły poświęcone historii Chełmży, jej katedry i kościołów.

Na stronach KPBC można obejrzeć także roczniki kalendarza „Pomorzanin", drukowanego w Wąbrzeźnie w latach 1924-1939 przez Bolesława Szczukę. Kalendarze te ukazywały się jako bezpłatne dodatki do „Głosu Wą-

${ }^{10}$ Stanisław Kubista urodził się w 1898 r. w Kostuchnie. W 1927 r. przyjął święcenia kapłańskie, zostając zakonnikiem zgromadzenia werbistów. Jesienią 1928 r. został skierowany do domu zakonnego św. Józefa w Górnej Grupie. Był nauczycielem gimnazjalnym, pełnił także obowiązki mistrza nowicjatu, wybudował i kierował drukarnią, redagował i publikował w „Małym Misjonarzu”, „Kalendarzu Małego Misjonarza”, „Kalendarzu Słowa Bożego”, „Skarbie Rodzinnym” i „Posłańcu Świętego Józefa”. Był współorganizatorem Muzeum Etnograficznego eksponatów z Chin, Brazylii i Nowej Gwinei. Został zamordowany w Sachsenhausen 26 kwietnia 1940 r. i beatyfikowany przez papieża Jana Pawła II w Warszawie w dniu 12 czerwca 1999 r. Cyt. za: Stanisław Kubista. W: Wikipedia. Wolna Encyklopedia [on-line] [dostęp 15 lipca 2009]. Dostępny w World Wide Web: http://pl.wikipedia. org/wiki/Stanisław_Kubista.

${ }^{11}$ Kronika Górnej Grupy, „Jubileuszowy Kalendarz Słowa Bożego na rok 1949”, s. 31-33. 
brzeskiego” oraz „Głosu Pomorza i Ziemi Warszawskiej”. Na łamach „Pomorzanina” publikowano artykuły dotyczące Pomorza, szczególnie Wąbrzeźna i okolicznych miejscowości. Poszczególne roczniki zawierały kronikę wydarzeń krajowych i zagranicznych, wiadomości kościelne, a także nowele, opowiadania, legendy i wiersze. „Kalendarz Głosu Pogranicza”, wydawany nakładem wydawnictwa "Głosu Pogranicza” w Brodnicy w 1932 r., drukowany w Zakładach Graficznych Bolesława Szczuki w Wąbrzeźnie, oprócz kalendarium wzbogaconego o przysłowia związane z każdym miesiącem, alfabetycznych spisów imion świętych i słowiańskich, zawierał listę szkół rolniczych w Wielkopolsce i na Pomorzu, wykaz jarmarków w województwie poznańskim i pomorskim oraz w Wolnym Mieście Gdańsku, tabele miar objętości i wagi, informacje dotyczące czasu tarła ryb słodkowodnych, kalendarz myśliwski i porady rolnicze. $\mathrm{W}$ kalendarzu przedstawiono władze wojskowe, powiatowe i miejskie z Brodnicy i Nowego Miasta Lubawskiego. Wiele miejsca zajmowały tu artykuły poświęcone sytuacji politycznej kraju, wspomnieniom Brodnicy sprzed I wojny światowej, a także dotyczące Gdyni i polskiego Wybrzeża. Teksty publikowane na łamach kalendarza uzupełniał ciekawy materiał fotograficzny. Nie zabrakło w nim również poezji, humoru oraz reklam firm działających w Brodnicy.

$\mathrm{W}$ ramach projektu realizowanego w BU udostępniono on-line także dwa kalendarze wydane w Nowym Mieście Lubawskim, tj. „Ilustrowany Kalendarz Głosu Lubawskiego" - wydany w 1935 r. w Drukarni B. Miłoszewskiego, oraz "Kalendarz Łąkowski” - ukazujący się w latach 1927-1939 jako dodatek do „Głosu Lidzbarskiego”, „Drwęcy” i „Głosu Mazurskiego". Obydwa kalendarze na swoich łamach publikowały wiele artykułów związanych z ziemią lubawską, a ponadto - podobnie jak w innych tego typu wydawnictwach - wiadomości z kraju i ze świata, spisy jarmarków, porady lekarskie, anegdoty i reklamy.

\section{Proces digitalizacji kalendarzy i jego efekty}

Drzed przystąpieniem do procesu konwersji cyfrowej wszystkie wytypowane kalendarze zostały opracowane formalnie i rzeczowo $\mathrm{w}$ formacie MARC 21, a ich opisy umieszczone w katalogu komputerowym BU. Przewidziane do digitalizacji wydawnictwa zostały przekazane do Pracowni Digitalizacji, która działa w ramach Oddziału Komputeryzacji i Digitalizacji BU. 
Skanowanie dokumentów odbywało się za pomocą kolorowego skanera OS1000 A1 firmy Zeutschel. W zależności od typu kalendarza (wydanie czarno-białe lub kolorowe) skanowano w kolorze (RGB 8-bitów na kanał) lub skali szarości (256 odcieni, 8-bit). Rozdzielczość skanowanego obrazu była najczęściej ustawiana na 300 dpi. Uzyskane skany zapisywano $\mathrm{w}$ formacie .tiff, a wszystkie nowo tworzone pliki poddawano kontroli pod względem jakości i kompletności. Do drobnych poprawek - typu obracanie i przycinanie obrazu - używano programu Photoshop CS2. Następnie - w celu archiwizacji - pliki nagrywano na płyty DVD, tworząc w ten sposób tzw. kopię matkę. Dla potrzeb platformy dLibra pliki zapisane $w$ formacie .tiff przetworzono za pomocą programu Document Express Professional na pliki .djvu. Zabieg ten pozwolił na znaczne zmniejszenie rozmiarów plików i dostosowanie ich do potrzeb prezentacji sieciowej. Przetworzone pliki .djvu umieszczono następnie na serwerze, skąd zostały pobrane przez redaktora KPBC i udostępnione wraz z opisem $\mathrm{w}$ formacie Dublin Core na platformie dLibra.

Po opublikowaniu kalendarzy w KPBC ich opisy bibliograficzne znajdujące się także w NUKAT uzupełniono o pola informujące o dostępie do wersji elektronicznej (pole 530 opisu bibliograficznego). Dodano także informację o lokalizacji źródła - adresy internetowe (pole 856), dzięki czemu z opisu bibliograficznego mieszczącego się w NUKAT, a także pobranego do katalogów lokalnych będzie można bezpośrednio przejść do wersji cyfrowej kalendarzy.

W ramach projektu „Kalendarze pomorskie...” udostępniono on-line 16 tytułów kalendarzy pochodzących ze zbiorów Biblioteki Uniwersyteckiej w Toruniu. Dzięki współpracy z Książnicą Kopernikańską w Toruniu i Biblioteką Miejską im. Kulerskiego w Grudziądzu udało się w wersji cyfrowej skompletować te roczniki kalendarzy, których brakuje w zasobach BU w wersji drukowanej. W KPBC opublikowano łącznie 75 roczników kalendarzy pomorskich wydawanych w pierwszej połowie XX w. Ich szczegółowy wykaz prezentuje poniższa tabela. 
Tabela. Wykaz tytułów i roczników kalendarzy pomorskich opublikowanych w KPBC

\begin{tabular}{|c|c|c|c|c|}
\hline Lp. & $\begin{array}{c}\text { Tytuł kalendarza, miejsce i data } \\
\text { wydania }\end{array}$ & 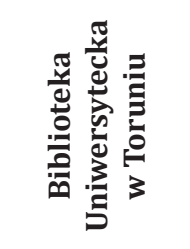 & 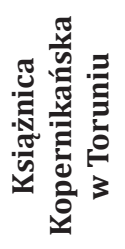 & 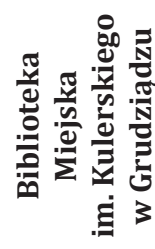 \\
\hline 1 & $\begin{array}{l}\text { „Grudziądzki Kalendarz } \\
\text { Maryański”, Grudziądz } \\
\text { (1905-1939) }\end{array}$ & $\begin{array}{c}\text { R. } 10(1915) \\
\text { R. } 12(1917) \\
1919-1920 \\
1926-1927 \\
1928 \text { cz. } 1-3 \\
1931 \\
1932 \\
1933 \\
1934 \\
1936 \\
1937 \\
1938 \\
1939\end{array}$ & 1930 & $\begin{array}{l}1922 \\
1924 \\
1925 \\
1929 \\
1935\end{array}$ \\
\hline 2 & $\begin{array}{l}\text { „Grudziądzki Kalendarzyk } \\
\text { Marjański”, Grudziądz } 1924\end{array}$ & 1924 & & \\
\hline 3 & $\begin{array}{l}\text { „Ilustrowany Kalendarz Głosu Lu- } \\
\text { bawskiego”, Nowe Miasto } 1935\end{array}$ & 1935 & & \\
\hline 4 & $\begin{array}{l}\text { „Ilustrowany Kalendarz Słowa Po- } \\
\text { morskiego”, Toruń 1929-1939 }\end{array}$ & $\begin{array}{l}1930-1931 \\
1937-1939\end{array}$ & $\begin{array}{l}1929 \\
1932\end{array}$ & \\
\hline 5 & $\begin{array}{l}\text { „Kalendarz Głosu Pogranicza”, } \\
\text { Brodnica } 1932\end{array}$ & R. 1 (1932) & & \\
\hline 6 & $\begin{array}{l}\text { „Kalendarz Jubileuszowy 30-lecia } \\
\text { Gazety Grudziądzkiej na rok 1925”, } \\
\text { Grudziądz } 1925\end{array}$ & 1925 & & \\
\hline 7 & $\begin{array}{l}\text { „Kalendarz Katolicki Wielkiego Po- } \\
\text { morza”, Toruń } 1939\end{array}$ & 1939 & & \\
\hline 8 & $\begin{array}{l}\text { „Kalendarz Kościelny dla Parafji } \\
\text { Chełmżyńskiej”, Chełmża } 1928\end{array}$ & 1928 & & \\
\hline 9 & $\begin{array}{l}\text { „Kalendarz Królowej Różańca } \\
\text { Świętego", Toruń 1937-1939 }\end{array}$ & $\begin{array}{l}1938 \\
1939\end{array}$ & & \\
\hline 10 & $\begin{array}{l}\text { „Kalendarz Ludowy”, } \\
\text { Toruń 1928-1939 }\end{array}$ & $\begin{array}{l}1929-1935 \\
1937-1938\end{array}$ & $\begin{array}{l}1928 \\
1936 \\
1939\end{array}$ & \\
\hline
\end{tabular}


Tabela. Wykaz tytułów i roczników kalendarzy pomorskich opublikowanych w KPBC (ciąg dalszy)

\begin{tabular}{|c|c|c|c|c|}
\hline Lp. & $\begin{array}{c}\text { Tytuł kalendarza, miejsce i data } \\
\text { wydania }\end{array}$ & 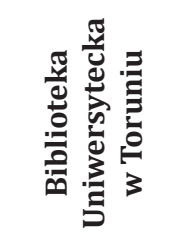 & 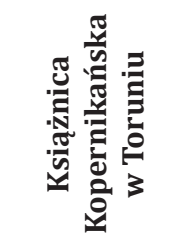 & 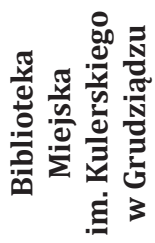 \\
\hline 11 & $\begin{array}{l}\text { „Kalendarz Łąkowski”, } \\
\text { Nowe Miasto 1927-1939 }\end{array}$ & $\begin{array}{c}1930 \\
1933-1934 \\
1936 \\
1938-1939\end{array}$ & & \\
\hline 12 & $\begin{array}{l}\text { „Kalendarz Pomorski”, } \\
\text { Toruń } 1928\end{array}$ & & 1928 & \\
\hline 13 & $\begin{array}{l}\text { „Kalendarz Roku Świętego”, } \\
\text { Grudziądz 1925-1926 }\end{array}$ & 1926 & & \\
\hline 14 & $\begin{array}{l}\text { „Kalendarz Słowa Bożego”, } \\
\text { Górna Grupa 1920-1940, } \\
\text { 1947-1949 }\end{array}$ & $\begin{array}{c}\text { R. } 8(1928) \\
\text { R. } 10(1930) \\
1936-1938 \\
1948-1949^{*}\end{array}$ & & \\
\hline 15 & $\begin{array}{l}\text { „Pomorski Kalendarz Rolniczy”, } \\
\text { Toruń 1924-1929, 1937, } 1939\end{array}$ & $\begin{array}{l}\text { R. } 2 \text { (1925) } \\
\text { R. } 3(1926) \\
\text { R. } 6(1929)\end{array}$ & $\begin{array}{l}1924 \\
1937\end{array}$ & \\
\hline 16 & $\begin{array}{l}\text { „Pomorzanin”, } \\
\text { Wąbrzeźno 1924-1939 }\end{array}$ & $\begin{array}{l}\text { R. } 6(1932) \\
\text { R. } 7(1933) \\
\text { R. } 9 \text { (1935) } \\
\text { R. } 11 \text { (1937) }\end{array}$ & $\begin{array}{l}\text { R. } 1 \text { (1924) } \\
\text { R. } 2 \text { (1927) } \\
\text { R. } 4 \text { (1930) } \\
\text { R. } 5 \text { (1931) } \\
\text { R. } 8 \text { (1934) } \\
\text { R. } 10 \text { (1936) } \\
\text { R. } 12 \text { (1938) } \\
\text { R. } 13 \text { (1939) }\end{array}$ & \\
\hline
\end{tabular}

* Roczniki powojenne objęte jeszcze prawem autorskim zostały opublikowane po uzyskaniu zgody od Wydawnictwa Księży Werbistów. Wydawnictwo to od 30 lat pod tym samym tytułem wydaje kalendarz nawiązujący do tradycji przedwojennego „Kalendarza Słowa Bożego".

Źródło: opracowanie własne. 


\section{Podsumowanie}

Drace związane z opisywanym projektem nie zostały jeszcze zakończone. Przed pracownikami BU kolejny etap, polegający na wyszukaniu w innych bibliotekach i przygotowaniu do digitalizacji brakujących roczników. Wstępna kwerenda przeprowadzona w bibliotekach pozwala ostrożnie prognozować, że w dużej mierze uda się uzupełnić braki. Na opracowanie i opublikowanie w KPBC czekają również kalendarze XIX-wieczne.

Mimo że projekt nie został jeszcze w pełni sfinalizowany, już dziś można zaryzykować stwierdzenie, że przyniesie on oczekiwane rezultaty. Z jednej strony przyczyni się bowiem do ochrony oryginalnych, lecz zaczytanych już publikacji drukowanych, z drugiej - do lepszego poznania tych często zapomnianych, a swego czasu bardzo popularnych wydawnictw ukazujących się w regionie. Należy żywić nadzieję, że zainteresują one studentów informacji naukowej i bibliotekoznawstwa, szczególnie zajmujących się prasoznawstwem w szerokim tego słowa znaczeniu. Być może zainspirują ich do podjęcia tematyki związanej z kalendarzami (analiza zawartości kalendarzy, monografia) w pracach licencjackich lub magisterskich. A może dostęp on-line do tych wydawnictw będzie po prostu okazją do ciekawej lektury dla miłośników Torunia i regionu, którzy z domowego zacisza będą mogli cofnąć się w czasie i zajrzeć na pożółkłe kartki przedwojennych kalendarzy.

\section{The Pomeranian calendars from the collections of the Torun University Library Abstract}

Scientific libraries are culture centers connected with tradition and fulfilling very important task of preservation and popularization of cultural heritage. The fast development of civilization makes the present day scientific libraries employ the information and communication technologies, including digitization. This enables them to participate actively in the process of globalization and creation of the information society. The article presents the project "Pomeranian calendars of XIX and the first half XX century from the collections of the Torun University Library - digitization and on-line access through Kujawsko-Pomorska Digital Library" which was started in 2008. Within the project were catalogued 16 titles of calendars (75 annuals) and made available on-line through Kujawsko-Pomorska Digital Library. The author of the article describes the project realization and some of interesting calendars from the collections of the Torun University Library. 